\title{
Characteristics of type I diabetes patients during first visit at Hiperdia Minas Center, Viçosa, MG
}

\author{
Daniela Neves Ribeiro*, Bruna Soares Faria, Flávia Xavier Valente, Milene Cristine Pessoa \\ From 20th Brazilian Diabetes Society Congress \\ Porto Alegre, Brazil. 11-18 November 2015
}

\section{Background}

The Hiperdia Minas Center in Viçosa aims to attend patients with chronic diseases such as hypertension, cardiovascular disease, diabetes mellitus and chronic kidney disease, referred by the Primary Healthcare Assistance. Thus, it is important to know the type 1 diabetes patients' profile of this Center in order to promote self-care actions.

\section{Objective}

Describe the profile of all type 1 diabetes patients first attended by the Hiperdia multidisciplinary team.

\section{Materials and methods}

All type 1 diabetes patients attended by the Hiperdia Minas Center were enrolled at the study, except for pregnant women. The data were collected from medical records at the first attending. At this first visit, the patients were attended by a physician, nutritionist, pharmacist, nurse, psychologist, physiotherapist, and social worker. Socioeconomics, anthropometrics, biochemistry and clinic data were assessed. Qualitative data were described as absolute and relative frequency, and the quantitative data as median, minimum, and maximum values.

\section{Results}

At the time of the study, 72 type 1 diabetes patients had the first visit at the Center. Out of these $54.2 \%$ were women. The minimum age was 3 months old, and the maximum 57 yrs. old. The median age was 20 yrs. old. Regarding nutritional status, $8.3 \%$ of the patients were obese; $22.2 \%$ were overweight or at risk of overweight; $65.3 \%$ were normal weight, and $4.2 \%$ were low weight. The median diagnosis time was 4 yrs.; the maximum time was 30 yrs., and minimum 6 days. The majority of the patients reported being single (72.2\%), having income below 1

\footnotetext{
* Correspondence: danielanevesribeiro@yahoo.com.br
} Centro Hiperdia Minas Viçosa, Viçosa, Brazil minimum wage (37.5\%), and less than 12 yrs. of study (84.8\%). Also, the majority of patients is not alcoholic or smoker, and almost 50\% did not practice physical activity. Regarding insulin type, the majority of the patients were using NPH or NPH + regular insulin (88.9\%), did not have comorbidities $(84.7 \%)$ and showed glycated hemoglobin above $7 \%$ (87.5\%).

\section{Conclusion}

It was observed that type 1 diabetes patients attended at the Hiperdia Minas Center are heterogeneous, showing the need to adapt the self-care promotion actions according to the patients' characteristics in order to favor more adhesion to the treatment.

Published: 11 November 2015

doi:10.1186/1758-5996-7-S1-A190

Cite this article as: Ribeiro et al:: Characteristics of type I diabetes patients during first visit at Hiperdia Minas Center, Viçosa, MG.

Diabetology \& Metabolic Syndrome 2015 7(Suppl 1):A190.

\section{Submit your next manuscript to BioMed Central and take full advantage of: \\ - Convenient online submission \\ - Thorough peer review \\ - No space constraints or color figure charges \\ - Immediate publication on acceptance \\ - Inclusion in PubMed, CAS, Scopus and Google Scholar \\ - Research which is freely available for redistribution

